fishery investigations consist of an account, by Prof. Meek, of the migrations of the grey gurnard. The eggs and pelagic larvæ of this fish drift passively inshore towards the Northumberland coast with the general set of the current, and with increasing size they then move offshore. The migrations are correlated with the direction of the movements of the water, but it is more probable that the seasonal variation of temperature is a more important factor. Study of the general direction and the annual shifting of the isotherms would bring out this relationship. Prof. Meek also writes on the migrations of the dab. Mr. Storrow has accounts of the age and rate of growth of herrings and pilchards taken off the coast of Northumberland. 'The herring investigations form part of the general scheme of biometric research carried on by the Board of Agriculture and Fisheries, but only data referring to the age of the fishes, as determined by a study of the scale-markings, are discussed in this report.

Mr. J. H. Paul contributes an interesting account of the phenomena of autotomy in the Decapod Crustacea, with reference mainly to the lobster and crab. It is well known that injury to, or forcible retention of, a limb leads to the breaking of the latter. Escape is suggested as the object of autotomy on the part of the lobster, but more often a limb is thrown off by the crab as the result of injury and as a means of arresting hæmorrhage. Mr. Paul has studied the anatomy of the parts affected, and has also made experiments on the actions of the muscles and nerves involved. His figures are rather difficult to follow, but he shows that autotomy of a limb always occurs by a fracture in the exoskeleton running partially round a "breaking-groove" in the third segment of the limb. The fracture is a pluri-segmental reflex, and it is effected as the result of antagonistic muscles. It occurs, in the lobster, in about four seconds after nocuous stimulation.

J. J.

\section{JAMES GEIKIE'S RESEARCHES IN GLACIAL GEOLOGY.}

A $T$ the meeting of the Royal Society of Edinburgh on November I, Dr. J. Horne, F.R.S., president of the society, delivered an address on "The Influence of James Geikie's Researches on the Development of Glacial Geology." At the outset reference was made to the appointment by the council of a committee to conduct investigations in connection with submarines, aeroplanes, asphyxiating gas, and high explosives. The experimental work had been carried out with the financial aid of an anonymous donor, whose generosity and patriotic spirit had been highly appreciated by the council.

The subject of the address had been chosen because James Geikie's researches in Glacial geology were the most striking feature in his scientific career. They stimulated inquiry and at the same time aroused keen opposition. Brief allusion was made to the state of research in this country when he began his investigations, how glacial phenomena were erroneously attributed to the action of icebergs, and how the clue to the correct interpretation was furnished by Agassiz during his visit to Scotland in 1840 . From the evidence which he obtained in the midland valley and in the Highlands he inferred that glaciers formerly existed there in post-Tertiary time.

The land-ice theory of Agassiz was adopted and confirmed by Buckland, Ramsay, Archibald Geikie, and Jamieson, but nearly a quarter of a century elapsed before the accuracy of this interpretation was adequately recognised. As James Greikie's field work in the Geological Survey proceeded he evolved certain No. 24.03 , VOL. 96] ideas regarding changes of climate in Pleistocene time, based on the succession of boulder-clays with intercalations of sand, gravel, and peat, and on the cave deposits and Palæolithic gravels in the south of England, which he afterwards published in 1874 in his volume "The Great Ice Age." He therein gave an account of the Glacial and post-Glacial deposits of the United Kingdom, Scandinavia, Switzerland, and North America. Through the whole description runs the principle, which he believed to be fundamental, that the Glacial epoch was not one continuous age of ice, but consisted of a series of cold and genial periods. In his discussion of the question of the age of the Palæolithic gravels and cave deposits in the south of England, he opposed the view held by many that they were post-Glacial, and referred them to inter-Glacial or pre-Glacial times. As regards the commingling of northern and southern mammals in these deposits, he combated the theory that this assemblage was due to seasonal migrations. He contended that the phenomena pointed to changes of climate.

These were the essential points in James Geikie's teaching which he never discarded. They encountered persistent opposition from the monoglacialists, who maintain the unity of the Glacial epoch, and ascribe the intercalated deposits to local movements of recession of the ice within one period of glaciation. Attention was next directed to his elaborate classification of European deposits, comprising six Glacial epochs separated by five genial periods. It was suggested that the fifth and sixth cold phases were not sufficiently severe to entitle them to be ranked as distinct Glacial epochs. If we eliminate the two last cold phases, his classification agrees with that of Penck and Brückner in the Alps. The evidence furnished by the Eemian clays, the Hötting breccia, the Dürnten lignite, the Don Valley section near Toronto regarding climatic changes in inter-Glacial time was reviewed. The opinion was expressed that sufficient evidence had been obtained to establish the general principle of oscillations of climate in the Glacial epoch, though the number of inter-Glacial periods may remain a subject of controversy.

\section{ZOOLOGY AT THE BRITISH ASSOCIATION.}

$A T$ its first meeting Section $D$ heard with profound regret that owing to serious illness the President of the Section, Prof. E. A. Minchin, was unable to be present. The presidential address, his last work, was read by $\mathrm{Mr}$. Heron-Allen, and a telegram was then sent to Prof. Minchin conveying to him the sympathy of the section and thanking him for his able address. The following is a summary of the communications presented to the Section.

\section{The Relation of Chromosomes to Heredity.}

In opening a discussion on this subject Prof. MacBride said that there seemed to be no escape from the position that the chromatin, viewed as a whole, is the bearer of the hereditary tendencies, for the influence of the father in determining the character of the offspring is as potent as that of the mother. The head of the spermatozoon, which is the only part of the father which enters into the constitution of the progeny, appears to consist practically exclusively of chromatin. The formation of the organs of an embryo is known in many cases to be due to substances localised in the cytoplasm, but the formation of these substances can be shown to be due to chromatic emission from the nucleus of the unripe egg. Prof. MacBride then considered the difficult 